\title{
後方型披裂軟骨脱臼症に対する徒手整復術
}

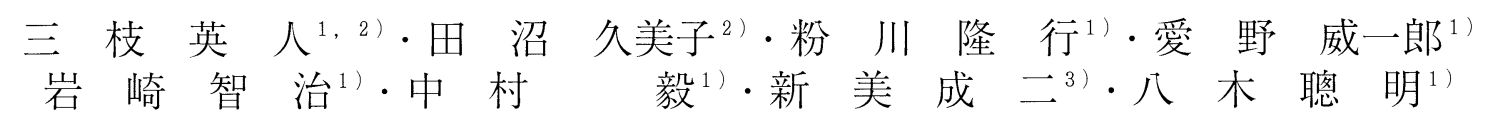

\section{Manual Closed Reduction for Posterior Arytenoid Cartilage Subluxation}

\author{
Hideto Saigusa ${ }^{1,2)}$, Kumiko Tanuma ${ }^{2)}$, Takayuki Kokawa ${ }^{1)}$, \\ Iichirou Aino ${ }^{1)}$, Chiharu Iwasaki ${ }^{1)}$, Tsuyoshi Nakamura ${ }^{1)}$, \\ Seiji Niimi ${ }^{3)}$ and Toshiaki Yagi ${ }^{1)}$
}

Subluxation of the arytenoid cartilage is an usual laryngeal injury that can occur following blunt trauma or medical instrumentation to the laryngeal cavity, for example endotracheal intubation. It is desirable for the reduction technique of the arytenoid cartilage subluxation to be performed easily without physical damage to the patient.

First, we morphologically observed and studied a model of the posterior arytenoid cartilage subluxation that had been extracted and prepared from human cadaver. This model demonstrated that the arytenoid cartilage had been displaced behind the posterior edge of the cricoid cartilage with the posterior cricoarytenoid muscle of the affected side. We could reduce the dislocated arytenoid cartilage manually with ease.

From these results, we have developed a new manual reduction technique for posterior arytenoid cartilage subluxation. The reduction procedure is follows.

(1) Turn over the patient's larynx manually for the affected faces from the surface.

(2) The dislocated arytenoid cartilage can be palpated at the inside of the thyroid cartilage lamina of the affected side (with tenderness).

(3) Pushing the dislocated arytenoid cartilage antero-medially, the affected arytenoid cartilage can be reduced manually by applying pressure until a clicking sound or response is achieved.

We performed the above procedure for 7 patients and found that their posterior arytenoid cartilage subluxation could be reduced with ease resulting in improvement of their symptoms (hoarseness, aspiration, odynophagia).

Key words : arytenoid cartilage subluxation, posterior arytenoid cartilage subluxation, closed reduction, manual closed reduction, laryngeal injury,

$$
\text { はじめに }
$$

披裂軟骨脱臼症は，気管内挿管を始めとした何らかの医 療行為に続発して起こることが多く1，2)，その診断，治療 には極めて慎重を要する。披裂軟骨脱臼の整復法には，喉 頭直達鏡下での非観血的整復術 ${ }^{1 \sim 3)}$ ，頸部外切開により輪 状披裂関節を固定する観血的整復固定術4,5)，甲状軟骨形 成術 $\left.{ }^{2}, 6\right) ，$ 披裂軟骨内転術7) などが報告されているが，そ の治療に際しては, 可能な限り患者への侵襲が少なく, 安 全で，かつ確実な治療方法であることが望ましい。

披裂軟骨脱臼症には，輪状軟骨の前内方に脱臼する前方
脱臼，後外方へ脱臼する後方脱臼の存在することが報告さ れているが，両者の治療方法の差異については，わずかに Sataloff ら ${ }^{1)}$ が, 前方脱臼では Holinger の喉頭微細手術 用ブレードを，後方脱曰 用ブレードを用いるのが良いと述べているのみで，その使 用方法や整復方法の詳細については記載がない。また，観 血的整復固定術や喉頭直達鏡下整復術など報告された治療 方法の多くは前方脱臼症例に対してのものである。一方， 後方脱臼についての治療法についての具体的記載は少な い1,8).ところで，脱臼の状態を考えた場合，披裂軟骨が 輪状軟骨の前内方へ脱臼している場合には行い得ないが,

1) 日本医科大学耳鼻咽喉科学教室

2 ）日本医科大学第 2 解剖学教室

3 ) 国際医療福祉大学言語聴覚学科学教室

1) Department of Otolaryngology, Nippon Medical School, Tokyo, Japan

2 ) Department of Anatomy, Nippon Medical School, Tokyo, Japan

3 ) Department of Speech/Language Pathology and Audiology, International University of Health and Welfare, Tochigi, Japan 


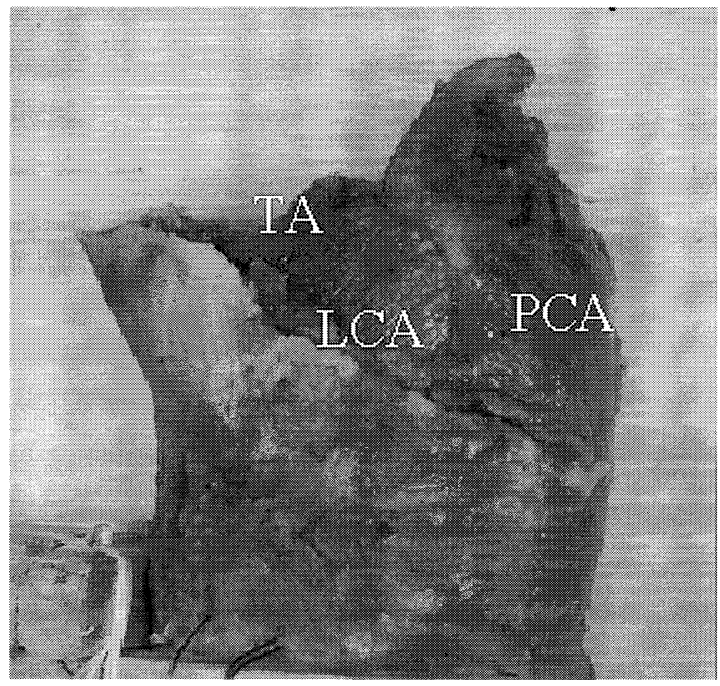

(a)

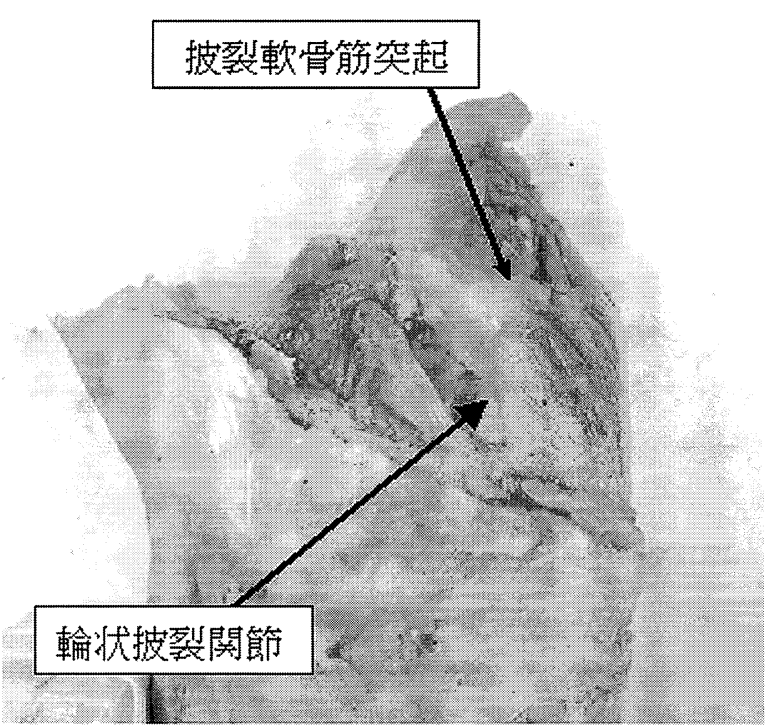

(b)

図1 後方型披裂軟骨脱臼モデルの作製

(a) 甲状軟骨板の上方を切除し，披裂軟骨筋突起とそれに付着する後輪状披裂筋（PCA），外側輪状披裂筋 （LCA），甲状披裂筋（TA）を明視下においた。

(b) LCA をその披裂軟骨筋突起付着部から切離し，輪状披裂関節を開放した．

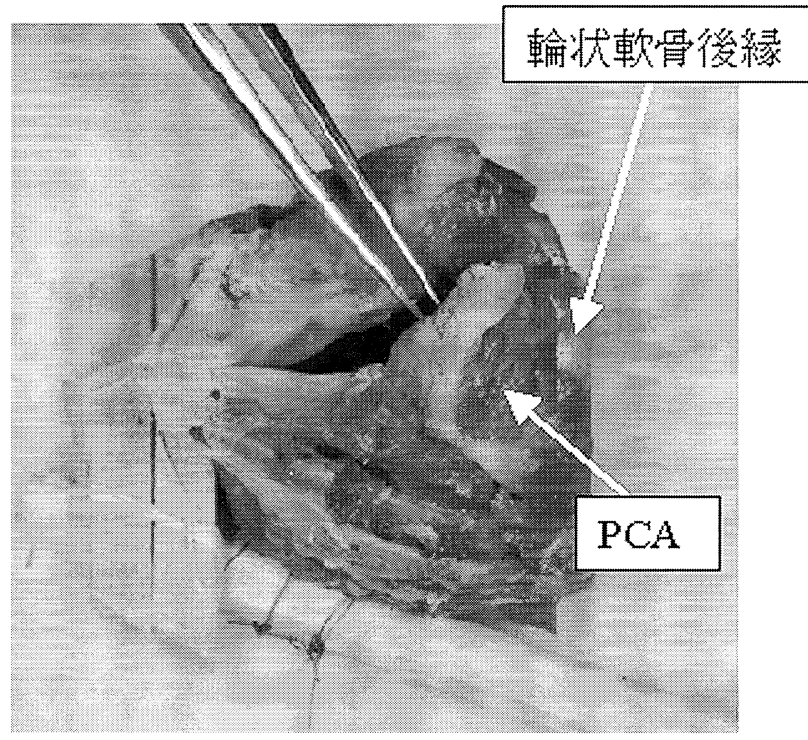

(a)

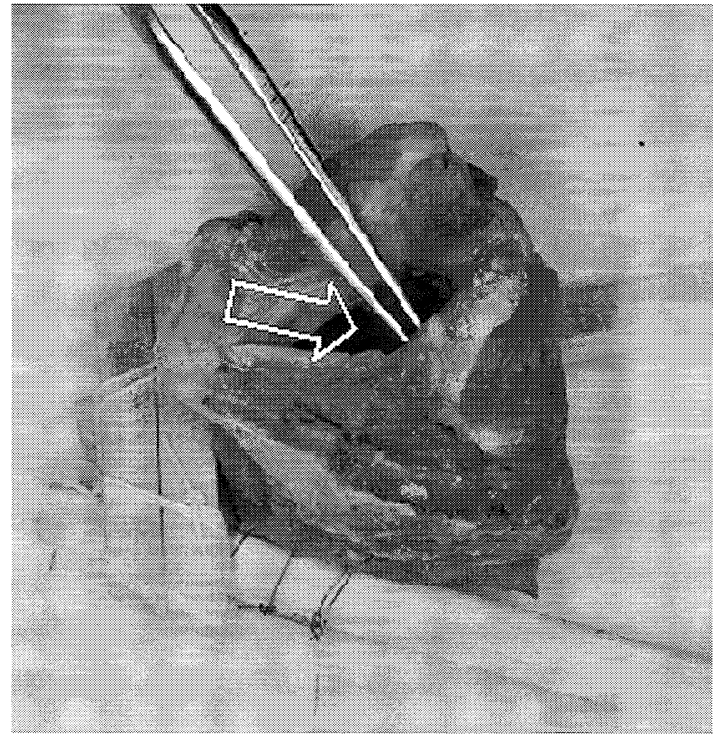

(b)

図 2 披裂軟骨後方脱臼前後の喉頭像の観察

(a) 脱臼前：披裂軟骨は輪状軟骨板後縁より前方に位置する.

(b) 脱臼後：摂子で披裂軟骨を後外方へ脱臼させると（矢印）, 披裂軟骨は輪状軟骨板後縁より後方へ突出す る.この時，披裂軟骨筋突起に付着する PCA も同時に後方へ変位する.

後外方へ脱臼している場合には，輪状披裂関節の後方から 脱曰した披裂軟骨を直接触知することができれば，更にそ れを前内方へ圧排することで, 容易に用手的に整復のでき る可能性があるのではないかと考えられる。

そこで，今回我々は，まず，ヒト摘出喉頭を用いて後方 型披裂軟骨脱臼症のモデルを作製し，その基礎形態学的観
察を行った。その結果を基に，後方型披裂軟骨脱臼症の治 療法について考案し, 更に実際に治療を試みたので, その 結果を報告する。

1. 後方型披裂軟骨脱田症の基礎形態学的研究

1 ) 目的：解剖体から摘出した喉頭を用いて後方型披裂軟 骨脱臼モデルを作製し, 脱臼前後の披裂軟骨の位置と周囲 
組織の関係について観察を行った。

2 ) 対象：生前に喉頭病変の無い解剖体から摘出したヒト 喉頭 2 体を用いて研究を行った. 甲状軟骨外板の上方を切 除し, 披裂軟骨筋突起とそれに付着する後輪状披裂筋（'以 下, PCA), 外側輪状披裂筋 (以下, LCA), 甲状披裂筋 （以下，TA）の走行を明視下におけるようにした（図 1 a). 次に, 対象は既にホルマリン固定された解剖体であり, 筋 および周囲組織の固縮が認められたため, 左右の披裂軟骨 の自由な運動性を得るために, 披裂間筋と, 披裂間粘膜を 正中で切断しておいた。 その上で, 披裂軟骨を他動的に脱 臼させた時に，喉頭の枠組みが歪まないよう輪状軟骨下端 を左右，前方から木製の枠組みで固定した。

3 ）後方型披裂軟骨脱臼モデルの作製：LCAを披裂軟骨 筋突起付着部から切離し, 輪状披裂関節と, その前方に続 く輪状軟骨弓の一部を剖出させた（図 $1 \mathrm{~b}$ ). 次に, 前方 から輪状披裂関節の関節包を切離し, 披裂軟骨を摂子で後 方に脱曰させ，その前後の披裂軟骨と輪状軟骨，および周 囲組織との関係について観察を行なった.

4 ) 結果：2 体の摘出喉頭を用いた実験結果はほぼ同様で あったので, 以下にその結果を示す.

脱臼前, 披裂軟骨は輪状軟骨板後縁より前方に位置して いたが (図 2 a), 後方脱臼時には, 披裂軟骨は輪状軟骨 の後縁よりも後方に, PCAを圧排しつつ突出することが 確認された（図 $2 \mathrm{~b}$ ). 更に, この脱臼した披裂軟骨を後 方から手指を用いて披裂軟骨を前内方へ圧排すると, 脱臼 前の位置に整復された。

5 ) 小括：我々の作製した後方型披裂軟骨脱巨モモデルから, 脱臼した披裂軟骨は輪状軟骨後縁よりも後方に, PCAを 圧排しつつ突出する。これを，外方より前内方へ圧排する と，脱臼した披裂軟骨を整復できることが確認された。 ヒトでは, PCAの付着している披裂軟骨筋突起は甲状軟 骨板を翻転させた時に, 甲状軟骨板外縁の内側で輪状披裂 関節から $1 \mathrm{~cm}$ 以内上方の位置に存在すると報告されてい $る^{9)}$. 従って, 甲状軟骨を外表から翻転し, 同部を触知す ることができれば，そのまま前内方に外力を加えることに よって後方脱臼が整復できる可能性が高いと考えられる.

2. 後方型披裂軟骨脱臼症に対する徒手整復法の考案

前述の基礎形態学的研究結果より, 後方型披裂軟骨脱臼 症に対する徒手整復術を以下のように考案した。
患側の輪状披裂関節を触知するには, 手指で健側甲状軟 骨板を内後方へ圧排して喉頭全体を翻転させ, 患側甲状軟 骨板の裏面にもう片側の手指を挿入する ${ }^{10)}$ ，その後，患側 甲状軟骨板外縁に沿って上方から下方へ辿り, 輪状軟骨を 触知すると, そのやや上内方に脱臼した披裂軟骨筋突起の 高まりを触知する。その後, 喉頭全体の枠組みを固定しつ つ, 後方脱臼した披裂軟骨を前内方へ圧排すれば, click 音, もしくは指先での “手応え”と共に整復される（図 3 ).

3. 後方型披裂軟骨脱臼症例に対する徒手整復術の成績 上述の方法に従って, 実際に治療を試みたので（図 4), その治療成績を以下に示す.

1 ) 対象：平成14年 4 月から平成15年 6 月までに日本医科 大学付属病院およびその関連病院を受診した後方型披裂軟 骨脱臼症例 7 名である (表 1 ). 左側のみの発症が 5 例, 右側のみが 1 例, 両側のものが 1 例であった. 全例とも, 脱臼は気道確保を伴う全身麻酔下手術後もしくは処置後に 発症していた。 6 例が気管内挿管, 1 例がラリンジアルマ スクによるものであったが, 症例 3,7 では気管内挿管チュー

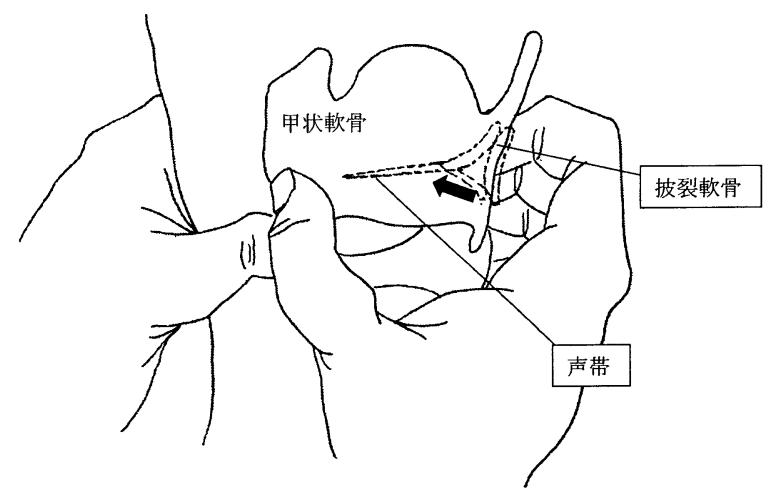

図 3 後方型披裂軟骨脱臼に対する徒手整復術の考案 (図は左側脱臼の場合)

手指で健側甲状軟骨板を内後方へ圧排し，喉頭を 翻転させると，患側甲状軟骨板裏面に手指が挿入 できる。毛ま，甲状軟骨板毫面下方で輪状軟 骨を触知すると, そのやや上内側に脱臼し, 後方 へ突出した披裂軟骨を触れる。それを前内方へ圧 迫すると(矢印)，クリック音もしくは“手応え” と共に整復される。

表 1 今回治療を行った後方型披裂軟骨脱臼症例とその内訳

\begin{tabular}{c|c|c|c|c|l}
\hline \hline 症例 & 年齢 & 性 & 障害側 & 発症からの期間 & \multicolumn{1}{|c}{ 発症前のエピソード } \\
\hline 1 & 34 & 男 & 左側 & 2 週間 & 気管内挿管 \\
2 & 48 & 女 & 右側 & 2 週間 & ラリンジアルマスク \\
3 & 49 & 女 & 左側 & 2 週間 & 気管内挿管およびその自己抜管 \\
4 & 54 & 男 & 左側 & 5 週間 & 気管内挿管 \\
5 & 64 & 女 & 左側 & 4 週間 & 気管内挿管 \\
6 & 69 & 女 & 左側 & 8 週間 & 気管内挿管抜去直後, 気管支内視鏡 \\
7 & 71 & 男 & 両側 & 3 週間 & 気管内挿管およびその自己抜管 \\
\hline
\end{tabular}



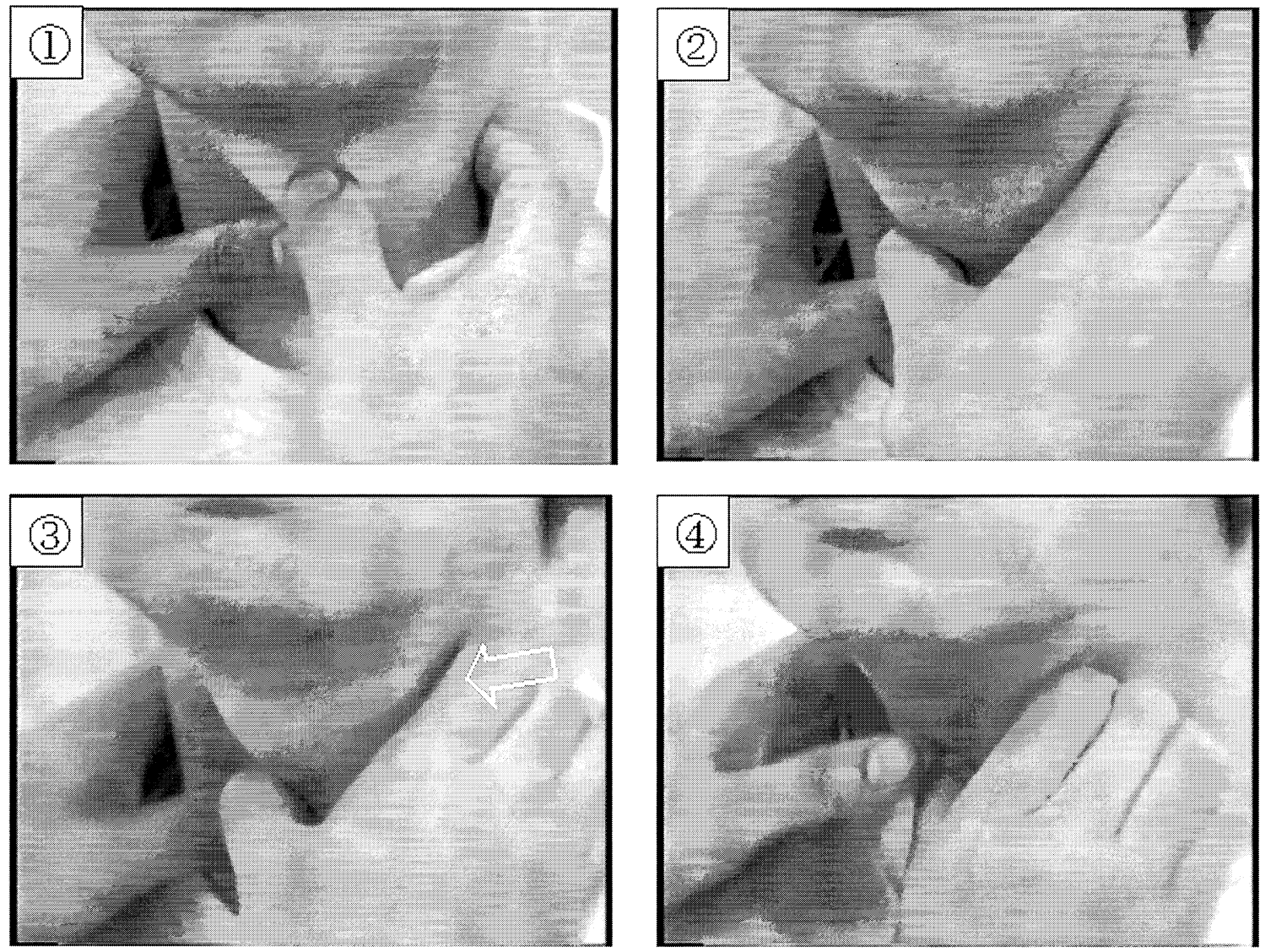

図 4 実際に後方型披裂軟骨脱臼症（左側）に対して徒手整復術を行っている場面（症例 1 ）

澒部の筋群を十分リラクゼーションさせた上で, 左手で患者の甲状軟骨板を内後方へ圧迫し, 喉頭全体を翻転 させた (1)). その時, 右手指先を患者の左側甲状軟骨板後縁の裏側へ挿人すると, 甲状軟骨板の下方で脱臼 した披裂軟骨を触知した（2)）。この時，患者は圧痛を訴えた。喉頭全体を動かないよう固定した上で，右手 指先で, 脱臼した披裂軟骨を前内方へ圧排した（矢印）(3)．クリック音と共に，脱臼が整復された（4)．

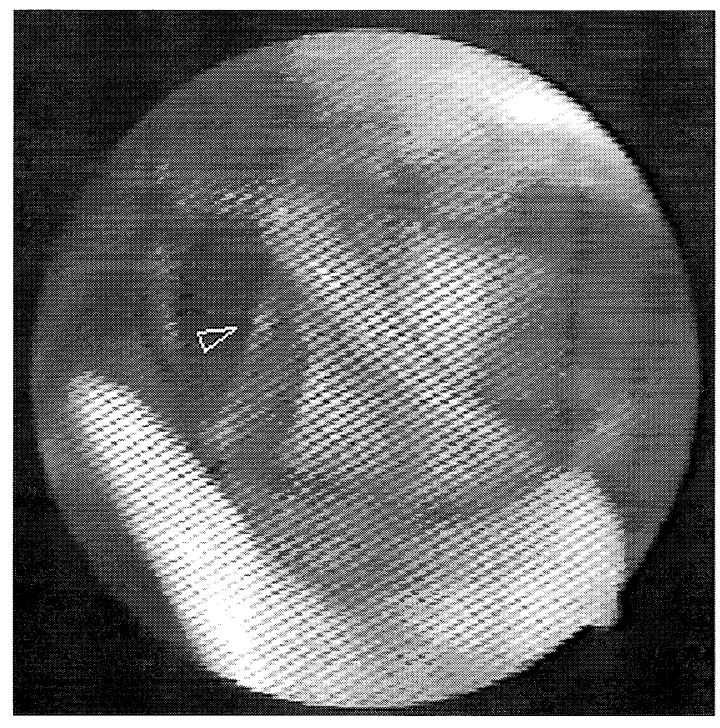

(a)

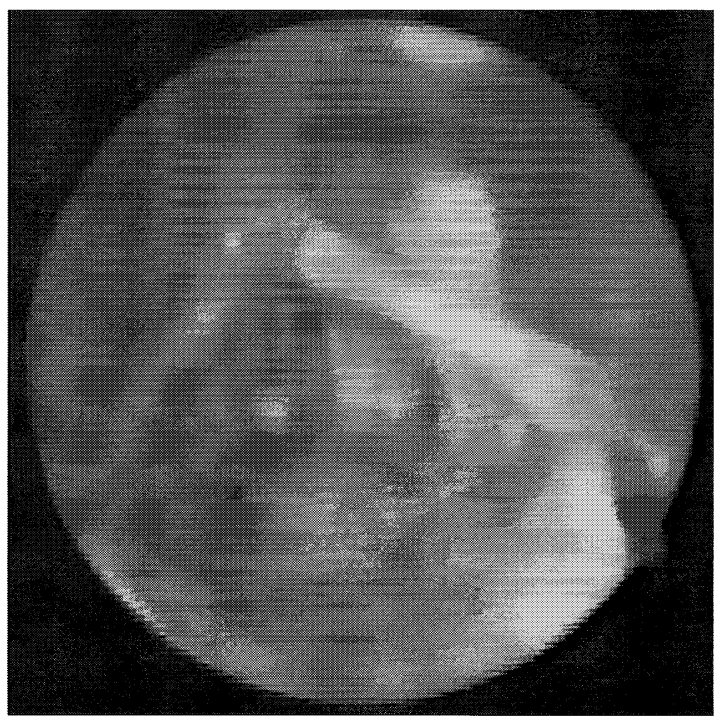

(b)

図 5 後方型披裂軟骨脱臼症（左側）の喉頭内視鏡所見（症例 1 )

左側声帯突起 (矢印) は後外側に位置し, 左側声帯は前後に緊張して観察される. 声帯の運動性も悪く, 発声 時に声門間隙を生じた。なお，本症例では発声時に，右側声带突起に圧排されて，左側声帯突起が外方へ変移 するという現象も観察された。(a) : 吸気時, (b) : 発声時 


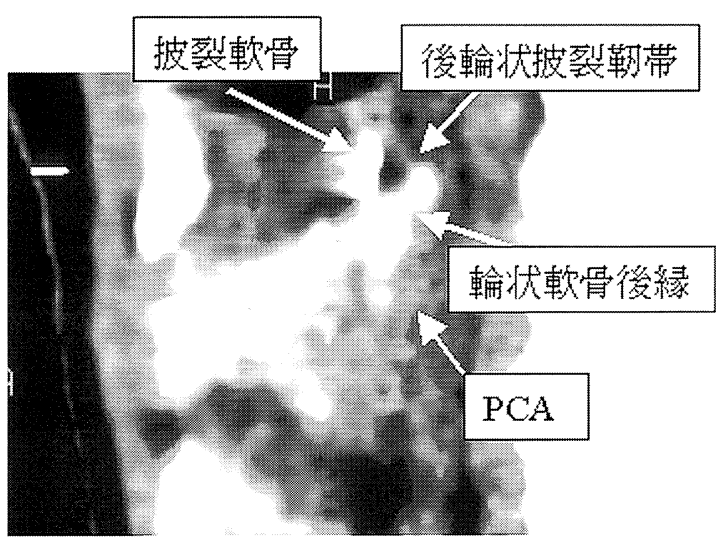

(a)

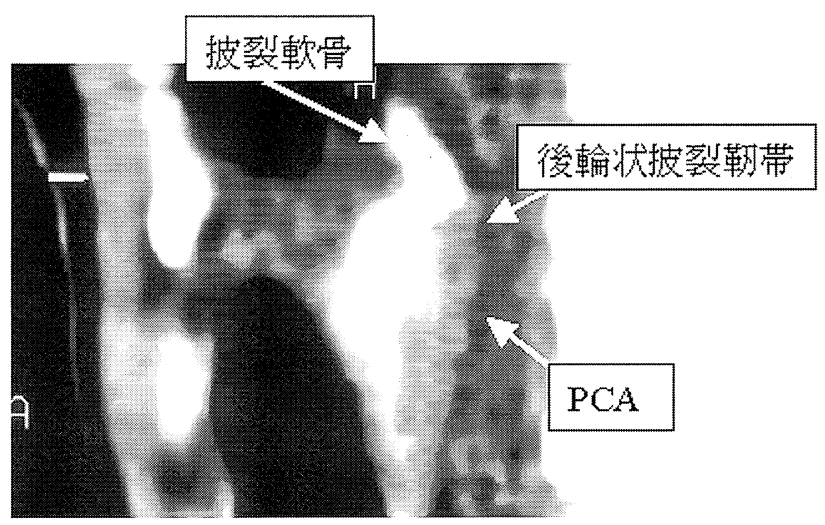

(b)

図 6 後方型披裂軟骨脱臼症（左側）の矢状断 CT 像（症例 3 )

健側では，披裂軟骨は輪状軟骨後縁より前方に位置するが，患側では，披裂軟骨は輪状軟骨後縁より後下方に 変位し，患側 PCA の厚みが増していることが指摘された。なお，本症例では矢状断 CT 像構成時に，声門軸 にCT 構成軸を合わせることができなかったため, 輪状披裂関節を構成する輪状軟骨，披裂軟骨，後輪状披裂 勒帯の 3 つが描出された部位で左右を比較した。(a)：右側（健側），(b)：左側（患側）

ブをカフが膨らんだ状態で自己抜管しており，また症例 6 では気管内挿管チューブ抜去後は問題なかったが，その直 後に行われた気管支鏡検査後より嗄声が出現したとのエピ ソードがあり，必ずしも気道確保の手技自体がその原因と は考えられなかった。発症からの経過は, 平均 3.7 週, 最 長のもので 8 週間という症例もあった. 全例, 気息性嗄声 と, 誤嚥, 燕下困難を自覚していた。症例 2 では嚥下時痛 を訴えていた。

2 ) 後方型披裂軟骨脱臼症の診断：全例で, 喉頭内視鏡に て, 脱臼側声帯が披裂軟骨声帯突起と共に後外方へ谹引さ れ，前後に緊張しており，声带の幅が狭く，また声帯運動 性は低下していた。この喉頭所見は反回神経麻痺の場合で は声带が弛緩して観察される点で異なっており，また輪状 披裂関節の固着が起こるにしても，その症状発現の時期が 早過ぎるため, 反回神経麻痺や輪状披裂軟骨固着症は否定 的であり，後方型披裂軟骨脱臼症と診断した（図 5 )。症 例 1，5では発声時に患側声帯突起が健側声帯突起に圧排 され，外方に変位するという現象も認められた（図 5 ). また， 2 例で矢状断 CTにて, 前述の形態学的研究を裏付 けるような画像が得られた (図 6 ). 症例 $1 \sim 6$ では, 単 音節/he/発声時の正面からのX 線透視にて, 脱臼の存在 を思わせる患側声帯の上方への異常可動性を認めた6, 11). また, 全例, 輪状披裂関節の触診で, 健側に比較して, 脱 臼側では圧痛を訴えた。なお，当初皮下脂肪の多い場合や 短頸者では，輪状披裂関節の触診は容易では無いかとも懸 念されたが，実際症例 1 ，5ではそのような症例であった が, 頸部筋肉を十分リラクゼーションさせた上で行うと十 分施行可能であった。

3 ) 治療結果：全例とも治療直後から, 上記の自覚症状は, 喉頭内視鏡像と共に改善を認めた。但し, その後の音声と 喉頭内視鏡像の完全回復には, 発症から 4 週間以内の症例
1，2，3，5，7では，治療後 2 週間以内に認められた が, 発症から 5 週間経過した症例 4 では, 治療後 8 週間で 更なる改善が得られたが, 完全回復には至らなかった（患 者の自覚では $60 \%$ 良くなったとのことであった)。発症か ら 8 週間経過した症例 6 では治療後 6 週間で完全回復した. なお，全例とも整復直後から発声禁止などの指導は特に行 わなかった。

$$
\text { 考察 }
$$

後方型披裂軟骨脱臼症の治療に際して, 解剖体から摘出 した喉頭を用いた基礎形態学的研究を行い，その結果に基 ついて徒手整復術を考案, 施行した所, 良好な結果を得る ことができた。また，治療後に，特に問題となるような副 作用も認めなかった，過去に，後方型披裂軟骨脱臼症の治 療法としては，全身麻酔下に喉頭直達鏡下で整復する方法 が報告されてきたが1, 8)，われわれの開発した徒手整復術 は外来で，麻酔も要せずに，容易に整復が行える点，整復 直後から症状の改善が得られる点で極めて有用であると考 えられる。また，後方型披裂軟骨脱臼症の診断にあたり， 輸状披裂関節の触診を行うことは，患側披裂軟骨が後方脱 曰したことに伴う同部の腫脹を触知し，またこれに起因す る PCAによるであろう圧痛を確認することは診断的意義 があるものと考えられる。

なお，全例とも，徒手整復術直後から自覚症状と共に喉 頭内視鏡所見の改善を認めたが，更に自覚上，また内視鏡 的にも完全回復を得るまでには，その後日数を要した。発 症から $2 \sim 4$ 週間と脱臼から比較的早期の症例 $1,2,3$, $5 ， 7$ では，整復後 2 週間以内に完全回復したが，それ以 上の脱臼から 5 週間以上経過した症例 4,6 では, 更なる 回復までに 6 週間以上を要した. 完全な回復が得られなかっ た症例 4 は, 糖尿性腎症による慢性腎不全にて透析中の患 
者であり, 整復までの時間が経過し, 更に脱臼に伴う関節 炎の回復するのが健常者に比較して遷延化していたことが 予想される. 恐らく, 輪状披裂関節周囲の線維化などによ り完全回復に至らなかった可能性が高い. 整復までに 8 週 間経過した症例 6 では, 整復後 6 週間で完全回復したが, 他に全身的疾患の既往は無かった。このように脱曰整復後 に完全回復するまでに時間を要するのは, 脱臼による機械 的炎症に伴う関節膜炎や, 後輪状披裂勒帯, 関節包などの 関節支持組織が伸展もしくは部分断裂しているためであろ うと考えられる. また, これに加えて, 輪状披裂関節は, 発声以外に呼吸, 嚥下, 息こらえ動作などに伴って, 終始 安静を強いることのできない関節であるということも関係 していよう。いずれにしても，これは披裂軟骨脱臼に限っ たことではないが, 脱臼後には, なるべく早期に整復され 得るのが良いものと考えられる。しかし, 症例 4, 6のよ うに発症から 1 ケ月以上経過した症例でも, 整復もしくは 改善され得る可能性があり, この徒手整復術を試みる価值 は多いにあるものと考えられる。

今回, 整復後に特に発声禁止などの指導を特に行わなかっ たが, その理由は以下の通りである。前述のように, 輪状 披裂関節は安静を保つことのできない関節であることと, 披裂軟骨を後方へ毫引する筋肉は PCAのみであるが，前 方へ毫引する筋肉は LCA, TA, 更には間接的ではあるが 輪状甲状筋と計 3 つあり, これら 3 つの筋肉により声帯内 転時には絶えず披裂軟骨は前方へ率引され，また後輪状披 裂勒帯は比較的強勒な勒帯であるので, 敢えて発声禁止な どの指導を行わずとも後方へ再脱臼する可能性は少ないと 考えたからである. 実際, 発声禁止などの制限は設けずと も，その改善には特に問題無かった。

$$
\text { ま と め }
$$

後方型披裂軟骨脱臼症についての基礎形態学的研究から, その徒手整復術を考案, 施行し, 良好な結果を得た. 今後, 本法は後方型披裂軟骨脱臼症に対して, 有用な治療法にな り得るものと考えられる。

\section{参 考 文 献}

1) Sataloff RT, Bough D, Spiegel JR: Arytenoid dislocation: Diagnosis and treatment. Laryngoscope 104: 1353 1361, 1994.

2) Hoffman HT, Brunberg JA, Winter PW et al : Arytenoid subluxation: Diagnosis and treatment. Ann Otol Rhinol Laryngol 100:1 9, 1991.

3）田村靖子, 平塚宗雄, 菊地茂ほか：披裂軟骨脱臼 一陳旧性披裂軟骨脱臼に対する非観血的整復固定術 の意義一. 日気食会報 $38 ： 279 \sim 282,1989$.

4) Morrison LF : The "reverse King operation". Ann Otol Rhinol Laryngol 57 : 945 956, 1948.

5) Montgomery WW : Cricoarytenoid arthroditis. Ann Otol Rhinol Laryngol 75:380 391, 1966.

6）三枝英人, 潮建司朗, 國友万由美ほか：前方型披裂軟 骨脱臼症の治療経験一甲状軟骨形成術の応用一, 日 気食会報 $47: 539 \sim 544,1996$.

7）樋口晶子, 中川千尋, 岩村節子ほか：輪状披裂関節脱 臼の 1 症例. 耳鼻 $29: 783 \sim 788,1983$.

8) Quick CA : Arytenoid dislocation. Arch Otolaryngol Head Neck Surg. 104:267〜270, 1978.

9）一色信彦: 喉頭機能外科, 第78回日耳鼻総会, 宿題 報告, 1977 .

10）小林武夫：喉頭の視診 - 触診. 臨床耳鼻咽喉科頭頸 部外科全書 10-A. pp75 79, 金原出版, 東京, 1986 .

11) Saigusa H, Kokawa $T$, Aino I et al : Arytenoid dislocation: A new diagnostic and treatment approach. J Nippon Medical School 70, 2003. (in press)

\footnotetext{
別刷請求先 $=113-8603$ 文京区千駄木 $1-1-5$ 日本医科大学耳鼻咽喉科学教室 三枝英人
} 